\title{
First Report of Carboxylic Acid Amide Fungicide Resistance in Plasmopara viticola (Grapevine Downy Mildew) in North America
}

\author{
Xuewen Feng and Anton Baudoin, ${ }^{\dagger}$ Department of Plant Pathology, Physiology and Weed Science, Virginia Tech, Blacksburg, 24061
}

Accepted for publication 3 April 2018.

Plasmopara viticola (Berk. \& M. A. Curtis) Berl. \& De Toni, the causal agent of grapevine downy mildew, is an oomycete plant pathogen that has the potential to cause large yield losses in humid grape-production regions worldwide. Chemical fungicides play an important role in controlling grape downy mildew, but $P$. viticola has developed resistance to several groups of fungicides, including quinone outside inhibitors, phenylamides, and carboxylic acid amides (CAAs) (Gisi and Sierotzki 2015). In Europe, resistance of grape downy mildew to CAA fungicides was detected before 2000 (Blum et al. 2010). Recently, control failure of CAA fungicides was also reported from vineyards in India (Sawant et al. 2017), and resistant isolates have been detected in Japan (Aoki et al. 2013) and China (Zhang et al. 2017).

Eight field isolates of $P$. viticola were collected in October 2016 from a vineyard in Virginia where mandipropamid (Revus $23.4 \%$ SC, Syngenta Crop Protection) was reported to have provided poor control of downy mildew. The spray program in this vineyard included three Revus applications in the 2016 growing season. Diseased leaf samples were brought to the lab on the Virginia Tech campus in plastic zipper bags and incubated overnight in a moist environment at room temperature (around $23^{\circ} \mathrm{C}$ ) to obtain sporulation. A sensitive isolate of $P$. viticola, collected before CAA fungicides were used in Virginia vineyards, was included as a reference isolate. Sensitivity to mandipropamid was determined by a leaf disc bioassay method (Sawant et al. 2017) modified as follows. Mandipropamid (Revus) suspensions of 200, 20, 2, 0.2, 0.02 , and $0 \mu \mathrm{g}$ of active ingredient (a.i.) per milliliter were prepared by dilution of a $1 \mathrm{mg} / \mathrm{ml}$ stock suspension with sterile deionized water. The experiment was conducted as a completely randomized design with three replicates. Fungicides were applied to the lower surface of approximately $15-\mathrm{mm}$ leaf discs placed on $1 \%$ water agar using a Preval sprayer (Precision Valve Corporation). Six hours later, $10 \mu \mathrm{l}$ of sporangial suspension $\left(10^{4}\right.$ sporangia/ml $)$ was inoculated in the center of each leaf disc. The inoculated leaf discs were incubated at room temperature (around $23^{\circ} \mathrm{C}$ ) with alternating periods of $13 \mathrm{~h}$ of light and $11 \mathrm{~h}$ of dark. After 6 to 7 days, the areas of the lesions were measured, and the numbers of sporangiophores were estimated with a dissecting microscope. Readings were expressed as a percentage of the untreated response and were plotted against the $\log _{10}$ fungicide concentration to calculate the $\mathrm{EC}_{50}$ value, the concentration estimated to inhibit pathogen development by $50 \%$. The $\mathrm{EC}_{50}$ value of the reference $P$. viticola isolate was $<0.2 \mu \mathrm{g} / \mathrm{ml}$, reflecting its sensitivity to mandipropamid. The $\mathrm{EC}_{50}$ values of the eight isolates from the commercial vineyard were $>240 \mu \mathrm{g} / \mathrm{ml}$ for mandipropamid, which was well above the

${ }^{\dagger}$ Corresponding author: Anton Baudoin; E-mail: abaudoin@vt.edu

Funding: This work was funded by the Virginia Wine Board.

(C) 2018 The American Phytopathological Society field rate (146 g/ha or $156 \mu \mathrm{g}$ of a.i./ml if applied by dilute spraying at 1,000 liters/ha), illustrating their insensitivity.

Additionally, the 144-bp $P v C e s A 3$ gene of two resistant isolates was amplified (Taq 2X Master Mix, New England Biolabs) and sequenced (Eurofins Genomics). The sequence showed that the polymerase chain reaction products amplified from the resistant $P$. viticola isolates had a GGC-to-AGC substitution at codon 1,105 of the PvCesA3 gene, the same G1105S mutation that has been found to confer CAA resistance in other regions (Aoki et al. 2013; Blum et al. 2010).

Nanni et al. (2016) described P. viticola isolates with this mutation, which were resistant to curative applications ( 1 day after inoculation) but still controlled by preventative applications (1 day before inoculation). However, our isolates were controlled by neither preventative nor curative application of mandipropamid in repeated trials. Dimethomorph (Forum, BASF Corporation, another CAA fungicide) was also tested in several experiments. At an approximate field-equivalent rate of $234 \mu \mathrm{g} / \mathrm{ml}$, dimethomorph reduced or eliminated growth of resistant isolates if applied before inoculation in most experiments but provided poor or no control if applied after inoculation, whereas the sensitive isolate was well controlled by after-infection applications. This behavior toward dimethomorph resembles that reported by Nanni et al. (2016).

In the 2017 growing season, we identified three additional vineyard locations where isolates with similar resistance phenotypes were collected, one $120 \mathrm{~km}$ north, one $175 \mathrm{~km}$ south-southeast, and one over $250 \mathrm{~km}$ southwest (in North Carolina) of the original site. Further mandipropamid resistance monitoring of downy mildew in commercial vineyards in the humid grape-growing regions of North America is needed to define the geographic extent of this emerging resistance.

\section{Literature Cited}

Aoki, Y., Hashimoto, M., and Suzuki, S. 2013. Emergence of single point mutation in $P v C e s A 3$, conferring resistance to CAA fungicides, in Plasmopara viticola populations in Japan. Online publication. Plant Health Prog.

Blum, M., Waldner, M., and Gisi, U. 2010. A single point mutation in the novel $P v C e s A 3$ gene confers resistance to the carboxylic acid amide fungicide mandipropamid in Plasmopara viticola. Fungal Genet. Biol. 47:499-510.

Gisi, U., and Sierotzki, H. 2015. Oomycete fungicides: Phenylamides, quinone outside inhibitors, and carboxylic acid amides. Pages 145-174 in: Fungicide Resistance in Plant Pathogens. H. Ishii and D. W. Hollomon, eds. Springer, Tokyo, Japan.

Nanni, I. M., Pirondi, A., Mancini, D., Stammler, G., Gold, R., Ferri, I., Brunellia, A., and Collina, M. 2016. Differences in the efficacy of carboxylic acid amide fungicides against less sensitive strains of Plasmopara viticola. Pest Manag. Sci. 72:1537-1539.

Sawant, S., Ghule, M., and Sawant, I. 2017. Occurrence of CAA fungicide resistance and detection of G1105S mutation in Plasmopara viticola isolates from vineyards in Sangli, Maharashtra, India. Plant Dis. 101:259.

Zhang, H., Kong, F., Wang, X., Liang, L., Schoen, C. D., Feng, J., and Wang, Z. 2017. Tetra-primer ARMS PCR for rapid detection and characterisation of Plasmopara viticola phenotypes resistant to carboxylic acid amide fungicides. Pest Manag. Sci. 73:1655-1660. 